\title{
KETIDAKADILAN GENDER DALAM NASKAH DRAMA MATA ADIL MATA TAKDIR KARYA TOTENK MT RUSMAWAN
}

\author{
Echo Dilus \\ (Pendidikan Bahasa Indonesia. Fakultas Keguruan dan Ilmu Pendidikan,Universitas \\ PGRI Adi Buana Surabaya) \\ Echosaogo10@gmail.com, luluk@unipasby.ac.id \\ Luluk Isani Kulup \\ (Pendidikan Bahasa Indonesia. Fakultas Keguruan dan Ilmu Pendidikan,Universitas \\ PGRI Adi Buana Surabaya) \\ luluk@unipasby.ac.id
}

\begin{abstract}
The purpose of this study is to describe gender injustice in the drama script Mata Adil Mata Takdir by Totenk MT Rusmawan. The theory used in this research is Fakih's theory which refers to gender injustice towards women as a support in his study. The method used in this study is a qualitative research method. Data collection techniques use words, sentences, and paragraphs. The technical analysis of the data used is reading, interpreting and concluding. The results of the research found in the drama script Mata Adil Mata Takdir there are gender injustices experienced by female characters by men contained in the drama script. Women leaders experience gender injustice by men in the form of job impoverishment, women 's numbering, and violence against women in terms of physical, psychological and rape violence. Conclusions in this study the forms of gender injustice in the lives of women leaders Gender differences have given birth to various injustices, both men and especially against women. injustice is a system and structure of both men and women become victims of the system. Suggestions in this research can be useful for the development of teaching Indonesian language and literature in understanding gender injustice contained in literary works, especially drama scripts.
\end{abstract}

Keywords : : Injustice, Gender, Women, Drama Scrip

\section{PENDAHULUAN}

Perempuan masih saja dijadikan sebagai objek kepentingan bagi kaum laki-laki. Hal ini terjadi karena di dalam perkumpulan masyarakaat dari segala lapisan. Risiko yang dialami oleh perempuan banyak yang terjadi dalam ketidakadilan dalam diri mereka sebagai perempuan,. jika kita lihat dari kelas sosial bahwa perempuan dianggap rendah banyaknya domestik yang harus dilakukan dari mulai merawat rumah hingga merawat anak dan suaminya. Hal ini terjadi

peneguhan pemahaman yang tidak pada tempatnya dimasyarakat, di mana apa yang sesungguhnya gender, karena pada dasarnya kontruksi sosial justru dianggap benar sebagai kodrat yang berarti sudah tuigas dan tanggung jawab utama perempuan sebagai "kodrat wanita". Oleh karena itu, jenis pekerjaan bisa dipertukarkan dan tidak bersivat universal, dalam kasus untuk mendidik anak dan mengatur kebersihan rumah tangga sesungguhnya adalah gender. hal ini dengan pendapat Fakih (2013: 12) 
bahwa perbedaan gender sesungguhnya tidaklah menjadi masalah sepanjang tidak melahirkan ketidakadilan gender (gender inequalities). Namun yang menjdi persoalan, ternyata perbedaan gender telah melahirkan ketidakadilan, baik bagi kaum laki-laki dan terutama perempuan. ketidakadilan gender merupakan sistem dan struktur di mana baik kaum laki-laki dan perempuan menjadi korban dari sistem tersebut.

Gender bukanlah kodrat ataupun ketentuan Tuhan, gender merupakan proses keyakinan dalam sosial dan budaya setempat bagaimana seharusnya laki-laki dan perempuan berperan dan bertindak sesuai dengan tata nilai yang terstruktur, ketentuan sosial dan budaya ditempat mereka berada. Dengan kata lain gender adalah pembedaan antara laki-laki dan perempuan dalam peran, fungsi, hak dan perilaku yang dibentuk oleh sosial dan buadaya. Istilah pada gender pada awalnya dikembangkan sebagai menganalisis ilmu sosial oleh Ann Oakley (1972), dalam Nugroho 2008:3), saat itu gender menurutnya gender dianggap sebagai alat analisis yang tepat untuk memahami persoalan deskriminasi terhadap kaum hawa secara umum. Umar (1999:35), menyatakan bahwa gender sebagai suatu konsep yang digunakan untuk menentukan atau menetepkan identitas perbedaan antara laki-laki dan perempuan dilihat dari sisi sosial budaya. Dalam pengertian tersebut menentukan atau menetapkan lakilaki dan perempuan dari dari segi nonbiologis. Dengan memperhatikan pengertian terserbut, berarti bahwa pemahaman dan perbedaan yang sangat jelas antara pengertian jenis kelamin (sex) dan gender itu diperlukan dalam membahas masalah ketidakadilan sosial, atau terkait dengan sosial lainnya. Pengertian gender ini sangat diperlukan memperhatikan dari konsep ini, Dengan demikian lahirlah suatu analisis gender. Gender merupakan bentuk keyakinan sosial budaya yang diyakini oleh manusia serta budaya dalam suatu masyarakat tentang bagaimana seharusnya peran laki-laki dan perempuan terlepas dari ikatan atau tindakan yang ditentukan oleh makhluk sosial. Perbedaan ini yang dibentuk oleh ketentuan sosial dan budaya dan yang bersifat biologis itu sudah ditentukan oleh Tuhan.

Kekerasan terhadap kaum perempuan yang dilakukan oleh kaum laki-laki maupun perempuan merupakan bagian dari kehidupan sosial masyarakat. Kehidupan masyarakat tidak ahanya dapat dilihat secara langsung, tetapi juga tercermin dalam karya sastra. Faruk, (2020,hlm 5), bahwa sastra sebagai cermin masyarakat. Berdasarkan hal tersebut, dapat diasumsikan bahwa kekerasan terhadap perempuan yang terjadi di dalam masyarakat juga dapat ditemukan dalam karya sastra, termasuk Naskah drama.Naskah drama adalah kesatuan dari teks yang membuat kisah. Naskah adalah karya fiksi yang memuat kisah atau lakon Endraswarah (2011:37) naskah semacam ini biasa di tulis oleh seseorang sutradara, aktor, dan spesialis naskah.

Naskah drama Mata Adil Mata Takdir adalah karya Totenk MT Rusmawan kelahiran bandung pada bulan Oktober 1982 yang lalu. Totenk terlahir dari seorang Ayah petani dan Ibu juru rias tradisional. Totenk juga asuhan dari W.S Rendra di bengkel teater Rendra. Beberapa karya Totenk MT Rusmawan sudah dimainkan digedung Cak Durasim 
Surabaya. Salah satunya karya Totenk MT Rusmawan yang dipentaskan di Gendung Cak Durasim, Taman Budaya Jawa Timur adalah "Mata Adil Maata Takdir". Pementasan teater ini digelar pada tangga 10 April 2019. Pertunjukan teater yang dimainkan 35 orang pemain dari Sanggar Lidi Surabaya, itu menceritakan sebuah tragedi tentang tokoh perempuan bernama Mata menjadi terdakwa divonis hukuman mati atas tuduhan sebagai dalang terjadinya perang saudara.

Terdapat sosok tokoh perempuan yang bernama Mata, adalah terdakwa yang divonis hukuman mati setelah mendapat tuduhan sebagai dalang dan aktor intelektual dari terjadinya perang saudara. Mata adalah sosok yang diciptakann sebagai tokoh yang membawakan kabar kebenaran dari permainan busuk para politisi yang menjual harga diri tokoh utama yang bernam Mata kepada investor asing. Oleh karena itu, Mata seolah menjadi musuh publik bagi para penguasa Negeri. Banyak kejadian yang dilami oleh Mata sehingga dia menjadi orang yang tertindas atau orang yang dikucilkan karean ia diperalat oleh penguasa negeri. Dari cerita di atas, diketahui tentang kejadian dan kejanggalan mengindikasikan perempuan masih sulit untuk menempatkan dirinya sebagai insan yang pantas untuk dihargai. Perempuan masih saja dijadikan sebagai objek kepentingan bagi kaum laki-laki. Hal ini terjadi karena di dalam perkumpulan masyarakaat dari segala lapisan. Risiko yang dialami oleh perempuan banyak yang terjadi dalam ketidakadilan dalam diri mereka sebagai perempuan,. jika kita lihat dari kelas sosial bahwa perempuan dianggap rendah banyaknya domestik yang harus dilakukan dari mulai merawat rumah hingga merawat anak dan suaminya. Hal ini terjadi peneguhan pemahaman yang tidak pada tempatnya dimasyarakat, di mana apa yang sesungguhnya gender, karena pada dasarnya kontruksi sosial justru dianggap benar sebagai kodrat yang berarti sudah tuigas dan tanggung jawab utama perempuan sebagai "kodrat wanita".

Dari paparan di atas, penelitian ini ingin menjawab permasalahan, bagaimanakah ketidakadilan gender dalam naskah drama Mata Adil Mata Takdir karya Totenk MT Rusmawan. hasil dari penelitian ini diharapkan dapat bermanfaat dalam memberikan kontribusi perkembangan ilmu sastra dan menjadi sarana pembelajaran dan pengetahuan selanjutnya.

Untuk menjawab masalah ketidakadilan gender terhadap tokohn utama perempuan yang bernama Mata ini, penulis menggunakan teori fakih. Fakih (2013: 12) menyatakan bahwa ketidakadilan gender merupakan sistem dan struktur baik kaum lakilaki dan perempuan menjadi korban dari sistem tersebut. Menurut Nugroho (2008: 09) ketidakadilan gender merupakan sistem dan struktur dimana kaum laki-laki dan perempuan menjadi korban dari sistem tersebut. Dalam kondidi saat ini perbedaan jenis kelamin (seks) dengan perbedaan gender saat ini masih menunjukkan bahwa perbedaan gender dimana kaum perempuan itu tidak rasional, emosional, dan lemah lembut; sedangkan laki-laki memiliki sifat rasional, kuat dan perkasa. Secara bilogis (kodrat) kaum perempuan dengan organ reproduksinya dapat hamil, melahirkan, dan menyusui, kemusian muncul gender role ( peran gender) 
sebagai perawat, pengasuh, dan pendidik anak. Dengan demikian gender role (peran gendera) dianggap tidak menimbulkan dan tidak dapat digugat entah apa teorinya mengapa tidak bisa di gugat, namun, yang menjadi masalah adalah cara sesuatu ketentuan (ketidakadilan gender).

Ketidakadilan dapat melahirkan perbedaan dan peran gender itu sendiri sehingga memberi nilai serta dalam pembagian tugas antara lakilaki dan perempuan dalam mempresepsi gender ini oleh perbedaan ketidakadilan suatu gender. Misalnya, perempuan harus dirumah tujuannya untuk menyelesaikan pekerjaan dalam rumah tangga tidak boleh bekerja. Arti dari kata lain hanya mengerjakan pekerjaan di dalam rumah saja sebagaimana peran dari ibu rumah tangga. Jadi, perbedaan gender dan perannya melahirkan sumber permasalahan ketidakadilan gender. Hal ini disebabkan oleh kurangnya kesadaran dalam suatu masyarakat bahwa mereka telah memaknai antara seks dan gender adalah sama. Padahal seks dan gender adalah dua sifat yang berbeda maknanya.

Kelemahan-kelemahan

perempuan tersebut acapkali menimbulkan dampak negatif pada perempuan. Berbagai dampak negatif yang dialami oleh permpuan terhadap laki-laki diantaranya adalah kekerasan. Kekerasan yang dialami oleh permpuan dapat berupa marginalisasi atau proses pemiskinan, subordinasi atau pandangan terhadap perempuan, stereotipe atau pelabelan negatif dan kekerasan. Kekerasan yang dialami oleh tokoh perempuan berupa kekerasan fisik, psikologis, dan kekerasan perkosaan.

Dari paparan di atas dapat diketahui bahwa ketidakadilan gender yang dialami oleh tokoh perempuan ketidakadilan gender terlahir adanya proses budaya perilaku mengutamakan laki-laki dari pada perempuan dalam masyarakat atau kelompok sosial tertentu yang disebut dengan patriarki. Oleh sebab itu lakilaki terlihat lebih berkuasa dari pada perempuan baik di masyarakat, politik, maupun di dalam rumah tangga tempat perempuan selalu mengalami deskriminasi.

Ketidakadilan gender atas pemahaman laki-laki terhadap perempuan adalah makhluk yang tertindas dan dipandang lemah, emosional, penuh perasaan sehingga tidak dipercaya mendapatkan peran sama sekali.

\section{METODE PENELITIAN}

Metode yang digunakan dalam penelitian ini adalah metode penelitian kualitatif. Menurut moleong (2014: 5) metode penelitian kualitatif adalah suatu metode yang menggambarkan atau memahami sesuatu dalam sebuah tindakan permasalahan yang ada bersifat alamiah yakni penelitian yang dimaksudkan untuk mengumpulkan data dalam bentuk kata-kata dan bahasa untuk memperoleh sebuah data pada objek yang alamiah. Menurut Djajasudarma (2010:7) penelitian deskriptif merupakan data yang dikumpulkan ini berasal dari sebuah wawancara, naskah, video tape, foto, dokumen pribadi, dan catatan lapangan yang digambarkan sesuai dengan inti sarinya kemudian, data disusun secara ilmiah, dan tulisan ilmiah ini harus diklarifikasikan menurut kriteria ilmiah tertentu dan memperoleh kebahasaan.

Tujuan penelitian ini adalah mendeskripsikan ketidakadilan 
gender dalam naskah drama Mata Adil Mata Takdir karya Totenk MT Rusmawan. Teori yang digunakan dalam penelitian ini adalah teori Fakih yang merujuk pada ketidakadilan gender terhadap kaum perempuan sebagai penunjang dalam kajiannya. Metode yang digunakan

\section{HASIL DAN PEMBAHASAN}

\section{Ketidakadilan Gender dalam Naskah Drama Mata Adil Mata Takdir Karya Totenk MT Rusmawan}

Ketidakadilan gender dalam naskah drama Mata Adil Mata Takdir karya Totenk MT Rusmawan dapat dilihat dari berbagai ketidakadilan yang dialami oleh kaum perempuan terhadap kaum laki-laki. Diantaranya adalah (1) marginalisasi

Subordinasi (3) Stereotipe dan (4) Kekerasan. Kekerasan yang meliputi (a) kekerasan fisik, (b) kekerasan psikologi, dan (c) kekerasan perkosaaan.

\section{(1)Marginalisasi dalam naskah drama Mata Adil Mata Takdir karya Totenk MT Rusmawan}

Marginalisasi atau proses pemiskinan, sesungguhnya banyak sekali terjadi dalam masyarakat dan negara yang menimpa kaum laki-laki dan perempuan, yang disebabkan oleh berbagai kejadian, misalnya penggusuran, bencana alam, atau proses eksploitasi. Gender ini sebagai akibat dari beberapa perbedaan jenis dan bentuk, tempat dan waktu, serta mekanisme dari proses marginalisasi perempuan. Gender differences bila ditinjau dari sumbernya dapat berasal dari akibat kebijakan pemerintah, keyakinan, tafsir agama, keyakinan tradisi dan kebiasaan atau bahkan asumsi ilmu pengetahuan. Hal ini dapat dijelaskan bentuk maginalisasi yang terdapat dalam penelitian ini adalah metode penelitian kualitatif. Teknik pengumpulan data menggunakan kata, kalimat, dan paragraf. Adapun teknis analisis data yang digunakan yakni membaca, menginterpretasi dan menyimpulkan.

dalam naskah drama Mata Adil Mata Takdir sebagai berikut.

Data 1

"Tetapi pikiran partai oposisi justru lebih sibuk menggagas bagaimana cara merebut, merebut, merebut kekuasaan dan tetap membunuhku."(A7. H11)

Dari data 1 di atas, dapat dijelaskan bahwa negara telah merebut kekuasaan perempuan sebagai korban terjadinya marginalisasi atau pemiskinan terhadap si korban. proses marginalisasi atau pemiskinan terhadap perempuan ini merupakan bentuk-bentuk ketidakadilan gender karena dianggap perbedaan gender tersebut. Akibatnya perempuan perempuan tersingkir dan selalu mengalami kemiskinan sehingga mendapatkan pekerjaan menjadi sebagai hambatan bagi mereka untuk bekerja. Bentuk marginalisasi kaum perempuan ini terjadi ditempat pekerjaan.

Selain marginalisasi dalam ranah pekerjaan, marginalisasi juga terjadi dalam rumah tangga. Marginalisasi dalam rumah tangga dialami oleh Mata yang harus hidup dengan keadaan miskin berusaha mencari nafkah untuk keluarganya. Hal ini terdapat pada kutipan berikut ini.

Data 2 
"benakku saat itu, bagaimana aku tetap hidup dan mampu memberikan pengobatan pada ayahku."(A7. H10)

Dari data 2 di atas dapat dijelaskan bahwa, proses marginalisasi atau pemiskinan ini dialami oleh Mata yang harus hidup dengan keadaan miskin berusaha mencari nafkah untuk pengobatan ayahnya, pasca ia dikeluarkan dari tempat kerjaannya. proses marginalisasi atau pemiskinan terhadap perempuan ini merupakan bentuk-bentuk ketidakadilan gender karena dianggap perbedaan gender tersebut.

\section{(2)Subordinasi dalam naskah drama Mata Adil Mata Takdir karya Totenk MT Rusmawan}

Subordinasi timbul sebagai akibat pandangan gender terhadap kaum perempuan. pandangan gender ternyata bisa menimbulkan subordinasi terhadap perempuan. anggapan bahwa perempuan itu irrasional atau emosional sehingga perempuan tidak bisa tampil memimpin, berakibat munculnya sikap yang menempatkan perempuan pada posisi yang tidak penting.

Anggapan tidak penting kepada perempuan atau subordinasi dapat dijelaskan sebagai berikut.

\section{Data 4}

"Mengapa orang-orang tertarik membebaskan Mata, seperti terpesona kisahnya, atau sekedar terpana dengan kecantikannya."'(A11. H19)

Dari data 4 di atas, dapat dijelaskan bahwa, pandangan gender ternyata menimbulkan subordinasi bahwa perempuan tidak bisa memimpin karena kaum perempuan dianggap irrasional atau emosional sehingga perempuan tidak bisa menempati seorang pemimpin. Dialog tersebut sebagian laki-laki meremehkan Mata tidak bisa memimpin diparatai politik, menimbukan subordinasi menganggap perempuan tidak punya hak untuk mendapatkan kedudukankaran dianggap perempuan itu lemah oleh laki-laki bahkan untuk dibela, berakibat munculnya sikap yang menempatkan perempuan pada posisi yang tidak penting. Tokoh perempuan tersebut mengalami penomorduaan dalam pekerjaan yang disebabkan oleh program pemerintah, bahkan pemerintah pernah memiliki peraturan bahwa jika suami akan pergi belajar (jauh dari keluarga) dia bisa mengambil keputusan sendiri. Sedangkan bagi istri yang hendak tugas belajar harus seizin suami. Praktik seperti itu sesungguhnya berangkat dari kesadaran gender yang tidak adil.

\section{Data 5}

"Bukan soal perempuan tak pernah dapatkan keadilan, tapi sebenarnya perempuan tidak akan pernah mampu menterjemahkan keadilan.’(A11. H20)

Dari data 5 di atas, dapat dijelaskan bahwa suatu penilaian atau anggapan bahwa suatu peran yang dilakukan oleh perempuan lebih rendah dari pada laki-laki. Anggapan bahwa kaum perempuan tidak mampu menerjemahkan keadilan karena perempuan sebagai makhluk irrasional yaitu yang cara berfikirnya tidak selaras dengan laki-laki, sehingga perempun tidak bisa tampil memimpin dibandingkan dengan laki-laki. Hal tersebut berakibat munculnya sikap yang menempatkan posisi perempuan yang tidak penting.

Perempuan tersebut mengalami subordinasi yang mengakibatkan 
ketidakadilan gender yang dialami oleh kaum perempuan menyebabkan para perempuan tidak bisa mengambil peran hak nya untuk melakukan apapun yang diinginkan oleh dirinya. Dengan demikian perempuan dinomorduakan oleh lakilaki dan membuat nasib perempuan tertindas akan dari segala bentuk batasan-batasan yang dibuat oleh pemerintah maupun laki-laki.

(3)Stereotipe dalam naskah drama

Mata Adil Mata Takdir karya

Totenk MT Rusmawan

Streotip adalah pelabelan atau penandaan negatif terhadap kelompok atau jenis kelamin tertentu. Pelabelaan atau penandaan negatif ini sering kali menyulit dan menyudutkan perempuan, baik itu membatasi, memiskinkan dan merugukan perempuan. Anggapan masyarakat bahwa perempuan yang bersolek dilakukan untuk memancing lawan jenis, bahkan jika ada korban pemerkosaan yang dialamim oleh perempuan, masyarakaat berkecenderungan menyalahkan korbannya. Masyarakat memiliki anggapan bahwa kaum perempuann tugas utamanya adalah melayani suami, yang berakibat pendidikan kaum perempuan dinomorduakan. Hal ini dapat dijelaskan sebagai berikut.

Data 6

"Dengan kau anggap bergabungnya Mata dengan partai politik adalah bentuk berubahnya paham feminisme dalam dirinya begitu."

$$
\text { (A11. H21) }
$$

Dari data 6 di atas, dapat dijelaskan bahwa, permpuan mengalami Pelabelaan atau penandaan negatif yang menyulit dan menydutkan perempuan dengan cara memiskinkan dan merugikan perempuan seolah-olah perempuan tidak layak untuk mendapatkan posisi dalam partai politik anggapan masyarakat ini menjadi penindasan terhadap kaum perempuan sebagai korban stereotip. Dengan adanya peraturan pemerintah sehingga menimbulkan dampak negatif bagi kaum perempuan terhadap pandangan gender, ketidakadilan terhadap jenis kelamin tertentu umumnya perempuan terhadap suatu kelompok merugikan dan menimbulkan ketidakadilan berakibat pendidikan bagi kaum perempuan menjdi tidak penting tiada lain selain dinomorduakan karena faktor stereotip tersebut.

\section{(4)Kekerasan dalam naskah drama Mata Adil Mata Takdir karya Totenk MT Rusmawan}

Terdapat bentuk kekerasan dan kejahatan yang bisa dikategorikan sebagai kekerasan gender yang terdapat dalam naskah drama Mata Adil Mata Takdir. Bentuk kekerasan diantaranya baik kekerasan fisik, kekerasan seksual maupun non seksual dan kekerasan psikis atau kekerasan yang belum sempat terjadi pada pukulan dan hantaman. Kekerasan adalah serangan atau invasi terhadap fisik maupun integritas maupun mental psikologi seseorang. Kekerasan terhadapa manusia pada dasarnya berrasal dari berbagai sumber, namun salah satu kekerasan terhadap salah satu jenis kelamin tertentu yang disebabkan oleh ketidaksetaraan kekuatan yang ada didalam masyarakat.

Bentuk kekerasan yang terjadi di dalam naskah Mata Adil Mata Takdir dalam hal ini adalah seperti pada kutipan berikut ini.

(a) Kekerasan Fisik 
kekerasan bentuk hal yang paling mudah dikenali, kategori jenis kekerasan ini adalah melempar, menendang, memukul atau menampar, mencekik, mendorong, mengigit, membenturkan, mengancam dengan benda tajam dan sebaginya. Korban jenis kekerasan ini biasanya tampak secara langsung pada fisik korban seperti luka, memar, berdarah, patah tulang, pingsan dan bentuk lain yang kondisinya lebih berat. Adapun bentuk kekerasan seperti kutipan dibawah ini.

\section{Data 7}

"namaku, Mata perempuan yang disajikan sebagai jawaban atas luka tumpah darah bangsa tumbal dari ketidakmampuan Bangsa dalam melihat permasalahan nyata bunuhlah aku dengan tega agar kesaksian kesaksianku terbunuh pula bungkamlah mulutku hingga lidahku tak mampu bersua maka segala kemufikan negeriku, akan tetap berjaya" (A2. H2)

Dari data 7 di atas menunjukkan bukti kekerasan yang dialami oleh Mata. Setelah sidang selesai saat itu pula mata bersaksi didepan semua orang atas putusan yang diberikan kepadanya tidak sesuai dengan kenyataan yang ada, mata selalu salah dihadapan banyak orang tanpa mereka melihat atau mengetahui permasalahan yang sebenarnya, ia tampak memberontak mengingat kejadian yang di alami oleh Mata, dirinya dijadikan tumbal sebagai penutup kesalahaan mereka atas peristiwa terjdinya perang saudara.

Kekeraan ini merupakan bentuk ketidakadilan yang dialami oleh tokoh perempuan yang menjadi korban, hal ini hasil dari produk kebencian terhadap individu maupun kelompok. Kekuasaan negara menjadikan kedudukan mereka sewenang-wenang merupakan semua bentuk kekuasaan dalam situasi politik yang dialami oleh tokoh perempun sebagai korban tersebut, dimana kejahatan dianggap hal yang wajar karena seseorang berpandangan dangkal berfikir dan menilai sesuatu, cenderung membuat tokoh perempuan mengalami ketertindasan berupa kekerasan fisik karena di ancam dalam bentuk pembunuhan.

Data 8

"Tahanan atas nama Mata, mohon bangun, dan segera ikuti saya! Hey bangun, bangkitlah! Jangan berpura-pura tak mendengar, baiklah dengan terpaksa akan kami seret,"( A10. H18)

Dari data 8 di atas, dijelaskan bahwa tokoh perempuan yang bernama Mata mengalami kekersan fisik yang dilakukan oleh pelaku atas perintah yang ia sampaikan kepada korban, yang mengalami tindakan kekerasan dengan memaksa tokoh perempuan untuk bangun dari tempat ia duduk sebelumnya. Kekerasan ini merupakan bentuk ketidakadilan pada suatu jenis kelamin, kaum permpuan sering mangalami tindak kekerasan seperti data tersebut. Kekerasan tumbuh dari sifat yang menyenangkan atau berupa amarah, kondisi saat ini menimbulkan reaksi yang tidak menyenangkan, secara otomatis amarah mengakibatkan tindakan serta sifat akan berubah.

\section{(b) Kekerasan Psikologi}

kekerasan psikologis adalah kekerasan yang berbentuk tekanan yang dapat menurunkan kemampuan mental dan otak. Bentuk-bentuk psikilogios yang dialami oleh korban mencakup makian dan penghinaan yang 
berkelanjutan untuk mengecilkan harga diri korban. Kekerasan adalah serangan atau invasi terhadap fisik maupun integritas maupun mental psikologi seseorang. Adapun bentuk-bentuk serangan psikilogis antara lain sebagai berikut.

Data 17

"Aku terlahir dirumah kumuh milik lelaki buruh bangunan, kala nafas pertama kuhela bersamaan dengan tangisan kala itu pula, hela nafas panjang Ibukku henti berulang. Saat usia pertumbuhanku, aku diusir dari sekolah, karena pertengkaran saat kutolak hidupku dihinakan."(A7. H9)

Dari data 17 di atas menunjukkan Mata mengingat kejadian di masa hidupnya disaat ia waktu kecil, ia menceritakan kisah hidupnya kepada tiga pemuka agama Kyai, Pastur, dan Resi bahwa hidupnya selalu dihina dan direndahkan oleh banyak orang, dari tempat ia menuntut ilmu diusir oleh pihak sekolah karena ia menolak atas hidupnya selalu dihina orangorang disekelilingnya.

\section{Data 25}

"Namun penguasa saat ini, menggelar pengusutan tentang terjadinya peristiwa perang saudara itu. Dan jadilah aku tersangka, dianggap sosok yang harus bertanggung jawab atas kematian banyak korban. . Dan setelah melewati berbagai sidang, diputuskan aku sebagai pelanggar hak Asasi Manusia atas tuduhan dan perencanaan mereka terhadap diriku, Bahkan HAM berat, dengan hukuman mati."(A7. H11)

Dari data 25 di atas, dapat dijelaskan bahwa, tokoh perempuan menceritakan kejadian yang di alaminya itu kepada tiga pemuka agama. Perempuan tersebut dituduh dan dianggap sebagai tersangka bahwa yang mengakibatkan terjadinya perang saudara, sehingga tokoh perempuan diancam dengan hukuman terberatnya hukuman mati.

Dari cerita di atas dapat diketahui bahwa, kekerasan psikologis yang dibuat pemerintah kepada perempuan mennyebabkan perempuan menjadi stress dan memiliki masalah trauma yang berkepanjangan akibat tindakan yang dilakukan oleh pemerintah terhadap perempuan atas dasar kekuasaan yang dimilikinya. Kalimat ancaman membuat perempuan tersebut menjadi takut. Ketakutan yang dialami oleh tokoh perempuan atas ancaman yang dilontarkan kepadanya dirinya bahkan HAM berat dengan hukuman mati. Kekerasan psikologis yang dialami perempuan dari suatu masyarakat yang memfitnah salah satu tokoh perempuan sehingga perempuan tersebut merasa terancam akibat ulah yang timbul oleh peran laki-laki yang ada di dalam masyarakat tersebut.

\section{(c) Kekerasan Perkosaan}

Pemerkosaan termasuk kekerasan fisk yang dialami perempuan oleh laki-laki. Perkosaan terjadi jika seseorang melakukan paksaan untuk mendapatkan pelayananseksual tanpa kerelaan bersangkutan. Ketidakrelaan ini sering kali tidak bisa terekspresikan disebabkan oleh pelbagai faktor, misalnya ketakutan, malu, keterpaksaan baik ekonomi sosial maupun kultur tidak ada pilihan lain. Adapun bentuk pemerkosaan sebagai berikut. 
Data 27

"Penangkapan seorang Boss besar Perusahaan, yang menodai gadis karyawannya."(A5.H6)

Dari data 27 di atas, dapat dijelaskan bahwa, tokoh perempuan mengalami problem perkosaan yang dialami tokoh perempuan tersebut terjadi akibat peran laki-laki yang tidak bisa menahan nafsu seks dirinya sendiri, akibat dirinya melampiaskan nafsunya kepada perempuan lain atas ancaman yang dilakukukan sehingga perempuan mengalami ketakutan atas ancaman laki-laki. Tokoh perempuan mengalami tindak perkosaan.

Data 30

"Aku dibayar oleh presiden dalam setiap informasi yang kuberikan terhadap gagasan partai oposisi."(A7. H11)

Dari data 30 di atas dapat dijelaskan, bahwa tokoh perempuan mengalami pelecehan seksual dalam bentuk perkosaan, di mana tokoh perempuan dibayar oleh tuan Presiden untuk imbalan seksual dalam rangka janji-jani untuk mendapatkan pekerjaan dari tuan Presiden. Perempuan menjadi objek bagi mereka yang berkuasa. Hal ini menyebabkan bentuk ketidakdalian gender yang dialami oleh kaum perempuan. kekerasan dalam bentuk pelayanan seksual ini mengakibatkan kaum perempuan dilecehkan dan dianggap rendah. Ketidakadilan ini merupakan bentuk bias gender yang menempatkan kaum perempuan rendah dimata masyarakat.

\section{SIMPULAN}

Berdasarkan hasil penelitian, dan pembahasan tersebut, Penelitian ini dapat disimpulkan bahwa di dalam naskah drama Mata Adil Mata Takdir tedapat bentuk-bentuk ketidakadilan gender dalam kehidupan tokoh kaum perempuan. naskah drama Mata Adil Mata Takdir karya Totenk MT Rusmawan merupakan naskah yang menceritakan berbagai macam sosial yang menyangkut tentang perempuan. masalah sosial tersebut yakni tentang ketidakadilan gender yang dialami kaum perempuan dan laki-laki.

Beberapa proses ketidakadilan gender yang dialami oleh tokoh kaum perempuan seperti marginalisasi, subordinasi, stereotip, dan kekerasan. Perbedaan gender telah melahirkan berbagai ketidakadilan, baik kaum laki-laki dan terutama terhadap kaum perempuan. ketidakadilan merupakan sistem dan struktur baik kaum lakilaki dan kaum perempuan menjadi korban dari sistem tersebut.

Di dalam proses marginalisasi yang dialami kaum perempuan dan membatasi hak-hak perempuan terdapat dalam naskah drama Mata Adil Mata Takdir. Bentuk marginalisasi ini berupa pemiskinan terhadap tokoh perempuan atas kebijakan pemerintah. Hal itu juga terdapat dalam bentuk subordinasi. Subordinasi timbul sebagai akibat pandangan gender terhadap kaum perempuan yang tidak dapat menyuarakan hak, pendapat dan keputusannya karena anggapan bahwa perempuan itu irrasional dan emosional sehingga tidak layak untuk mendapatkan kedudukan yang sama antara laki-laki dan perempuan. Proses stereotip juga di alami oleh perempuan akibat menandaaan negatif terhadap kelompok atau jenis kelamin tertentu yang memiskinkan dan merugikan kaum perempuan. terdapat juga dalam bentuk kekerasan terhadap perempuan 
dalam bentuk kekerasan fisik, kekerasan psikologi, dan bentuk kekerasan perkosaan.

\section{DAFTAR PUSTAKA}

Endraswara, Suwardi. 2014. Metedo Pembelajaran Drama. Yogyakarta: PT. Buku Seru. Fakih, Mansour. 2013. Analisis Gender \& Tfansformasi Sosial. Yogyakarta: Pustaka Pelajar.
Handayani dan Sugiarti.2008. Konsep dan Penelitian Gender. Malang: UMM Press.

Moleng, L. J. 2010. Metode Penelitian Kualitatif, Bandung: Remaja Rosda Karya

Nugroho, Riant. 2008. Gender dan Strategi Pengurus-Utamanya Di Indonesia.Yogyakarta: Pustaka Pelajar.

Sugiyono.2014. Metode Penelitian Kuantitatif Kualitatif dan $R \& D$. Bandung: Alvabeta. 